\title{
AVALIAÇÃO DE TANGERINAS, TANGORES E TANGELOS EM RELAÇÃo À CLOROSE VARIEGADA DOS CITROS ${ }^{1}$
}

\author{
SIMONE RODRIGUES DA SILVA ${ }^{2,3}$, JOÃO CARLOS DE OLIVEIRA ${ }^{4}$, EDUARDO SANCHES STUCHI ${ }^{5}$, \\ LUIZ CARLOS DONADIO ${ }^{6}$, PAULO SÉRGIO DE SOUZA ${ }^{7,8}$, ELENA PAOLA GONZÁLEZ-JAIMES $^{7,9}$
}

\begin{abstract}
RESUMO - A Clorose Variegada dos Citros (CVC), causada pela bactéria Xylella fastidiosa, é uma séria ameaça à citricultura brasileira, constituindose, atualmente, numa das principais doenças dos citros no Brasil. O objetivo desse trabalho foi avaliar cultivares de citros introduzidas quanto à suscetibilidade ou resistência à CVC, em condições de campo. O trabalho foi conduzido em Bebedouro-SP. Os materiais genéticos estudados foram cultivares de tangerinas e híbridos (tangores e tangelos) introduzidas de bancos de germoplasma da Itália, Portugal, Espanha e Córsega. O trabalho foi constituído por 56 parcelas, com três plantas das quais uma foi inoculada, empregando-se o método de encostia, utilizando-se de mudas previamente infectadas como fontes da bactéria. Foram avaliados os sintomas da doença mediante observação visual através de notas e teste de PCR, específico para Xylella fastidiosa. Os materiais genéticos que se apresentaram positivos ao PCR, mas não apresentaram sintomas, e os que foram negativos ao PCR, possuem um potencial de utilização em programas de melhoramento genético visando à resistência e/ou à tolerância à doença.
\end{abstract}

Termos para indexação: Citrus reticulata Blanco, inoculação, melhoramento, resistência, variedades, Xylella fastidiosa.

\section{EVALUATION OF MANDARINES, TANGORS AND TANGELOS IN RELATION TO THE CITRUS VARIEGATED CHLOROSIS (CVC)}

\begin{abstract}
The Citrus Variegated Chlorosis (CVC), caused by the bacteria Xylella fastidiosa, is a serious threat to the Brazilian citriculture, being, actually, one of the mains diseases to the citrus in Brazil. The objective of this work was evaluate citrus cultivars, introduced according to the susceptibility or resistance to CVC, in field conditions. The research was carried in Bebedouro city - São Paulo state - Brazil. The genotypes studied were cultivars of mandarines and hybrids (tangors and tangelos), introduced from the germplasm collections of Italy, Portugal, Spain and Corsica. The work was composed by 56 portions, with 3 plants, being one of them inoculated, using the approach graft method, with infected plants. Were evaluated the symptoms of the disease by visual observation and PCR test, specific to Xylella fastidiosa. The genotypes that had positive results to the PCR test, but did not presented symptoms, and the ones that were negative to the PCR, have great possibilities to be used in genetic improvement programs, aiming resistance and/or tolerance to the disease.
\end{abstract}

Index terms: Citrus reticulata Blanco, inoculation, improvement, resistance, varieties and Xylella fastidiosa.

\section{INTRODUÇÃO}

A clorose variegada dos citros (CVC) é causada pela Xylella fastidiosa, bactéria limitada ao xilema e responsável por outras doenças em culturas como a uva, ameixa e pêssego (Purcell \& Hopkins, 1996). Identificada inicialmente no Norte do Estado de São Paulo (Rossetti \& De Negri, 1990), disseminou-se rapidamente por todas as regiões citrícolas brasileiras, causando sérios prejuízos. Estima-se que as perdas com a doença já tenham ultrapassado os 650 milhões de reais (Prejuízos..., 2001).

A bactéria pode ser transmitida por meio de borbulhas contaminadas ou por insetos vetores das famílias Cicadellidae e Cercopidae, que se alimentam nos vasos do xilema das plantas (Purcell, 1994). Onze espécies de cigarrinhas são comprovadamente transmissoras da bactéria (Fundecitrus, 1999). A doença compromete o desenvolvimento das plantas e a produção dos frutos. Internamente, o fruto tem suas características organolépticas bastante afetadas (Laranjeira \& Palazzo, 1999). A CVC ataca quase todas as cultivares comerciais de laranja-doce no Brasil (Lee et al., 1992). Tangerinas e seus híbridos, como tangores e tangelos, podem apresentar sintomas em condições de campo, embora numa intensidade bem menor que nas laranjas-doces. Até o momento, esses sintomas foram constatados apenas em cultivares não comerciais (Laranjeira et al., 1998a,b; Laranjeira, 2002).

A doença pode ser detectada por observação de sintomas e por métodos de diagnóstico sorológicos e moleculares. Dentre eles, os testes moleculares implicam maior sensibilidade e precisão, portanto a técnica de PCR proporciona um diagnóstico rápido e seguro, sem a presença de reações inespecíficas, detectando cerca de $10^{2}$ a $10^{3}$ bactérias/ $\mathrm{mL}$, sendo, portanto, mais sensível que os sorológicos (Misanvage et al., 1994).

O objetivo do trabalho foi avaliar a reação de 46 cultivares de tangerinas, sete de tangelos e três de tangores, em relação à CVC, por observação de sintomas e testes de PCR, considerando o potencial de uso destes materiais genéticos para utilização em melhoramento genético e possível obtenção de híbridos resistentes à doença, além de seu aproveitamento como cultivares comerciais.

\section{MATERIALEMÉTODOS}

O trabalho foi conduzido em condições de campo, na Estação Experimental de Citricultura de Bebedouro, (EECB) situada no município de Bebedouro-SP, Brasil (latitude 2053'16" S, longitude 48²8' 11' W, clima Cwa: subtropical-inverno moderado e seco, verão quente e chuvoso. Os materiais genéticos estudados foram cultivares de tangerinas (Citrus reticulata Blanco) e híbridos (tangores- Citrus reticulata Blanco x Citrus sinensis (L.) Osbeck e tangelos - Citrus reticulata Blanco x Citrus paradisi Macf), introduzidos pela E.E.C.B. de bancos de germoplasma da Itália, Portugal, Espanha e Córsega com a colaboração da Embrapa, Cenargen e Fundecitrus. Os materiais genéticos estudados, bem como as avaliações realizadas, encontram-se na Tabela 1.

a) Implantação e Condução do Experimento: Parte dos materiais genéticos foi introduzida por sementes e parte por borbulhas. Os materiais

\footnotetext{
${ }^{1}$ (Trabalho 152/2003). Recebido: 13/06/2003. Aceito para publicação: 13/04/2004.

${ }^{2}$ Mestre em Agronomia, Depto. Fitotecnia FCAV/UNESP. Via de Acesso Prof. Paulo Donato Castellane, s/n - CEP 14870-000, Jaboticabal-SP. simoni@ viazul.com.br.

${ }^{3}$ Bolsista FUNDECITRUS

${ }^{4}$ Prof. Dr. Depto. Produção Vegetal FCAV/UNESP. Via de Acesso Prof. Paulo Donato Castellane, s/n - CEP 14870-000, Jaboticabal-SP.

${ }^{5}$ Embrapa Mandioca e Fruticultura/Agrobiologia - Rod. Brigadeiro Faria Lima, Km 384, CP 74 - CEP 14700-970, Bebedouro-SP. stuchi@ cnpmf.embrapa.br.

${ }^{6}$ Prof. Dr. Aposentado Depto. Produção Vegetal FCAV/UNESP. Via de Acesso Prof. Paulo Donato Castellane, s/n - CEP 14870-000, Jaboticabal-SP.

${ }^{7}$ Doutorando Depto. Produção Vegetal FCAV/UNESP. Via de Acesso Prof. Paulo Donato Castellane, s/n, CEP 14870-000, Jaboticabal-SP.

${ }^{8}$ Bolsista FAPESP

${ }^{9}$ Bolsista CNPq
} 
genéticos introduzidos por sementes foram semeados em tubetes, passaram por seleção para a eliminação das possíveis plantas de origem zigótica e foram transplantados para sacolas plásticas e mantidos em casa de vegetação até atingirem condições ideais para o plantio no campo. Aqueles introduzidos por borbulhas foram enxertados em porta-enxertos de limoeiro 'Cravo' e conduzidos até o momento de serem plantados no campo. Nos dois tipos de introdução, o tamanho da muda levada ao campo foi de $50 \mathrm{~cm}$ de altura com, no mínimo, $7 \mathrm{~mm}$ de diâmetro. De cada material genético, três mudas foram plantadas no campo, em fevereiro de 2000 , onde receberam tratos culturais recomendados para a cultura de citros. O espaçamento utilizado foi de 7,0 x 3,0 metros.

TABELA 1 - Resultado do teste de PCR e avaliação de sintomas de CVC em variedades de citros introduzidas em condições de campo na E.E.C.B.

\section{VARIEDADES}

Clementina Tomatera SRA 535

Tangor Dweet IVIA-C-165 (N)

Clementina De Nules VCR

Clementina Caffin SRA 385

Clementina Bruno SRA 531

Clementina Oroval SRA 335

Satsuma Saigon SRA 227

Mand. East India SRA 414

Mand. Redskin SRA 428

Mand. Beuty Of Glen Retreat SRA 261

Mand. Malvasio SRA 115

Mand. Rodeking SRA 431

Tangelo Mapo (N)

Tangerina Cami (N)

Tangelo Nova IVIA $-74-7(\mathrm{~N})$

Tangelo Nova IVIA $-86-2(\mathrm{~N})$

Clementina Reina SRA 534

Clementina Commune SRA 92

Tangor Clemelin IVIA 355

Satsuma Kowano SRA 167

Satsuma Miyagawa SRA 444

Satsuma Salzara SRA 341

Mand. Burgess SRA 412

Mand. Macaque SRA 426

Mand. Anan ás SRA 410

Tangerina Carvalhaes Vidigueira (N)

Mandarina 'Vaso' (N)

Mand. Antillaise SRA 497

Mand. Ampefy SRA 495

Mand. Fewtrell SRA 418

Tangelo Page SRA 159

Mand. C-54-4-4 SRA 337

Mand. Natal Tightskin SRA 481

Mand. Encore SRA 190

Mand. Changs ha SRA 413

Mand. Fortune SRA 31

Mand. Wallent SRA 438

Tangerina Carvalhais (N)

Setubalense Proc. 49/97 (N)

Ciaculi 60/22a/2 Proc. 435/96 (N)

Tangelo Allspice SRA 327

Clementina Commune SRA 88

Tangelo Nocatee SRA 452

Clementina 2kr Monreal

Tangelo Thornton Vero SRA 460

Tangor H-56 SRA 465

Clementina Nules SRA 389

Mand. Temple Sue Linda SRA 467

Mand. Fuzhu SRA 599

Mand. Lebom SRA 425

Mand. Poncã Yoshida SRA 585

Mand. Late Emperor SRA 423

Clementina Oroval Y. 45

Mand. Zanzibar SRA 442

Clementina Commune SRA 85

Tangelo Mapo SRA 450

SRA 261

\section{PCR PCR Fev./02 Maio/03}

SINTOMAS ${ }^{1}$

\begin{tabular}{|c|c|c|c|c|}
\hline Nov./01 & Mar./02 & Jul./02 & Dez./02 & Jun./03 \\
\hline
\end{tabular}


b) Obtenção de ramos como fontes da bactéria Xylella fastidiosa e inoculação: Para a obtenção dos ramos infectados por $X$. fastidiosa, inicialmente, foram preparados cavalinhos de limoeiro 'Cravo', com aproximadamente $15 \mathrm{~cm}$ de altura, foram retiradas e envolvidas as raízes juntamente com o substrato, em papel jornal embebido em água e, por fim, foram envolvidos em saco plástico devidamente amarrado, formando assim uma câmara úmida. Esse cavalinho foi enxertado por encostia em ramos de planta adulta de 'Pêra', que apresentava sintomas típicos de CVC em folhas e frutos, comprovados por testes de patogenicidade. Após 30 a 40 dias da enxertia, fez-se o desligamento (desmame) das mudas, fontes da bactéria, e foram mantidas em câmara de nebulização onde mostraram sintomas. Em janeiro de 2001, as mudas, fontes de bactéria obtidas, foram então enxertadas através do método de encostia em uma das três plantas da parcela com as cultivares em estudo, mantendo-as com seus próprios sistemas radiculares até o pegamento.

c) Teste (PCR) - "Polymerase Chain Reaction": O procedimento de extração do DNA foi realizado de acordo como o protocolo proposto por Shilito \& Saul (1988). A quantificação, com base em Sambrook et al. (1989), e, para a reação de PCR, foi utilizado primer específico para Xylella (Wichert, 2001).

d) Avaliações de sintomas: A presença de sintomas típicos da CVC foi avaliada mediante a técnica da observação visual através das seguintes notas: 0- planta sem sintoma; 1- planta com algumas folhas até um ramo com sintoma; 2- 50\% da planta com sintomas; $3-100 \%$ da planta com sintomas. As avaliações foram efetuadas nas seguintes datas: novembro de 2001; março, julho e dezembro de 2002, e junho de 2003.

\section{RESULTADOS E DISCUSSÃO}

Nas três primeiras avaliações (novembro de 2001 e março e julho de 2002), nenhum material genético apresentou sintomas (Tabela 1). Na quarta avaliação, realizada em dezembro de 2002, dois materiais genéticos manifestaram sintomas, o Tangor 'Dweet IVIA-C-165' e o Clemelin 'IVIA 355'. Na quinta e última avaliação, realizada em junho de 2003, além dos anteriores, apenas a tangerina 'Cami' apresentou sintomas. Vale ressaltar que nestes materiais genéticos sintomáticos, os sintomas se apresentaram somente nas folhas do ramo onde a bactéria foi inoculada. Não houve até o momento redução no tamanho dos frutos, mesmo estando próximo a pomares com alta pressão de inóculo e com inoculação realizada há dois anos. O fato de as plantas estarem com três anos e quatro meses de idade e dois anos e cinco meses de inoculação, não garante que, no futuro, quando estiverem em plena produção, os sintomas apareçam nos frutos.

O tempo decorrido da inoculação ao aparecimento dos sintomas foi de 23 meses para os dois primeiros materiais genéticos e de 29 meses para a tangerina 'Cami'. Souza et al. (2000), avaliando alguns materiais genéticos em relação à $\mathrm{CVC}$ em condições de casa de vegetação, verificaram que a variedade de tangerina 'Cami' apresentou sintomas dez meses após a inoculação e foi positiva aos testes de PCR e ELISA.

O Tangor 'Dweet', neste trabalho, apresentou sintomas nas folhas, divergindo dos resultados de Souza et al. (2000), que relataram apenas testes positivos para o referido material genético, mas não à presença de sintomas em condições de casa de vegetação. Laranjeira (2002) relatou a presença de sintomas foliares no Tangor 'Dweet' em áreas com alta pressão de inóculo. Em condições de campo, os sintomas só foram detectados nos tangelos 'Page', 'Swanee' e 'Williams' (Laranjeira et al., 1998a). Os autores mencionam que a multiplicação da bactéria em tangelos não é muito rápida ou eficiente, uma vez que sua presença foi detectada somente por PCR. Embora Laranjeira et al. (1998b) relatem sintomas foliares apenas nas cultivares Carvalhais, Wilking, Tankan, Bower, Clementina X Honey, Emperor e noTangor Dweet, em condições de campo e alta pressão de inóculo, com base nos resultados obtidos, podem-se acrescentar os materiais genéticos Clemelin 'IVIA 355' e 'Cami' como hospedeiros sintomáticos da bactéria. Neste trabalho, a tangerina 'Carvalhais' não apresentou sintomas foliares, apenas teste positivo ao PCR.

Na primeira avaliação de PCR, realizado 13 meses após a inoculação, verificou-se que, dentre os materiais genéticos, 27 apresentaram-se negativos quanto ao teste, ou seja, 48,2\% do material avaliado. Aos 28 meses após a inoculação, apenas as cultivares Clementina de Nules VCR, Clementina Caffin SRA 385 e o Tangelo Mapo SRA 450 foram negativas ao PCR, ou seja, apenas 5,4\% dos materiais genéticos. Donadio et al. (2001) relataram teste positivo de PCR e ELISA para a Clementina de 'Nules VCR' em condições de estufa, oito meses após a inoculação.

Os materiais genéticos positivos ao PCR e com sintomas, como as cultivares de Tangor Dweet IVIA-C-165; Clemelin IVIA 355 e tangerina Cami, seriam hospedeiros sintomáticos segundo a classificação proposta por Laranjeira et al. (1998b), em condições de alta pressão de inóculo (Tabela 2). Considerando a classificação proposta por Li et al. (2000),

TABELA 2 - Classificação dos genótipos avaliados quanto à reação da CVC, divididos por grupos, segundo a classificação proposta por Laranjeira et al. (1998b) e Laranjeira (2002).

\begin{tabular}{|c|c|}
\hline Grupos & Classificação \\
\hline \multirow[t]{3}{*}{ Tangerinas } & $\begin{array}{l}\text { Variedades hospedeiras sintomáticas: } \\
\text { Cami }\end{array}$ \\
\hline & 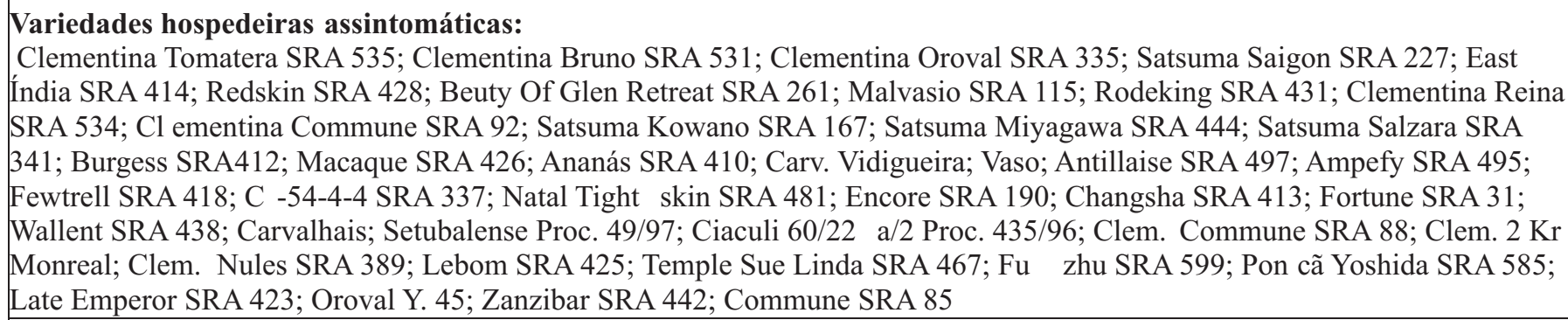 \\
\hline & $\begin{array}{l}\text { Variedades não-hospedeiras: } \\
\text { Clementina de Nules VCR; Clementina Caffin SRA } 385\end{array}$ \\
\hline \multirow[t]{2}{*}{ Tangores } & $\begin{array}{l}\text { Variedades hospedeiras sintomáticas: } \\
\text { Dweet IVIA-C-165, Clemelin IVIA } 355\end{array}$ \\
\hline & $\begin{array}{l}\text { Variedades hospedeiras assintomáticas: } \\
\text { H-56 SRA } 465\end{array}$ \\
\hline Tangelos & $\begin{array}{l}\text { Variedades hospedeiras assintomáticas: } \\
\text { Page SRA 159; Mapo; Allspice SRA 327; Nocatee SRA 452; Thornton Vera SRA 460; Nova IVIA -74-7; Nova IVIA-86-2 } \\
\text { Variedades não-hospedeiras: } \\
\text { Mapo SRA } 450\end{array}$ \\
\hline
\end{tabular}


estes materiais genéticos seriam suscetíveis à CVC. Aqueles positivos ao PCR e sem sintomas seriam classificados como hospedeiros assintomáticos segundo Laranjeira et al. (1998b) e Laranjeira (2002) (Tabela 2). Para Li et al. (2000), estes materiais genéticos devem ser considerados tolerantes à doença.

As cultivares Clementina de Nules VCR; Clementina Caffin SRA 385 e o Tangelo Mapo SRA 450 não mostraram sintomas e foram negativas ao PCR. Conforme Laranjeira et al. (1998b) e Laranjeira (2002), estas cultivares seriam classificadas como não-hospedeiras da bactéria (Tabela 2). Já segundo Li et al. (2000), estas cultivares seriam classificadas como resistentes à CVC.

Estes resultados, além de trazerem informações práticas a respeito de cultivares potencialmente comerciais frente à CVC, apresentam cultivares com possibilidades de uso em programas de melhoramento genético visando à obtenção de híbridos resistentes à doença.

\section{CONCLUSÕES}

1) As cultivares e híbridos de tangerinas que não mostraram sintomas, independentemente de serem positivas ou negativas ao PCR, apresentam possibilidades de uso em programas de melhoramento genético visando à resistência e/ou à tolerância à Clorose Variegada dos Citros.

2) Os resultados positivos dos testes PCR demonstram a eficiência da inoculação da Xylella fastidiosa pelo método de encostia adotado.

\section{REFERÊNCIASBIBLIOGRÁFICAS}

DONADIO, L.C. et al. Resistência varietal à CVC. Jaboticabal: FUNEP, 2001.29p. (Boletim Citrícola,19).

FUNDECITRUS. Descobertos mais seis vetores de CVC. Revista do Fundecitrus, Araraquara,v.14, n.94, p.7-8, 1999.

LARANJEIRA, F.F. et al. Screening for tolerance of citrus to Xylella fastidiosa, the causal agent of citrus variegated chlorosis CVC. Fruits, Paris, v.53, n.5, p.345-349. 1998a.

LARANJEIRA, F.F. et al. Cultivares e espécies cítricas hospedeiras de Xylella fastidiosa em condição de campo. Fitopatologia Brasileira,
Brasília,v.23, n.2, p.147-154. 1998b.

LARANJEIRA, F.F.; PALAZZO, D. Danos qualitativos à produção de laranja 'Natal' causada pela clorose variegada dos citros. Laranja, Cordeirópolis, v.20, n.1, p.77-91, 1999.

LARANJEIRA, F.F. Comportamento em campo de variedades cítricas frente à clorose variegada dos citros. Cruz das Almas: Embrapa, 2002.4p. (Comunicado Técnico, 80).

LEE, R. F. et al. Development of a serological assay for citrus variegated chlorosis - a new disease of citrus in Brazil. Proceedings Florida State Horticulture Society, Winter Haven,v. 105, p.32-34, 1992.

LI, W. B. et al. Susceptibility of tangerines to citrus variegated chlorosis. Acta Horticulture, Wageningen, n.535, p.253-257, 2000.

MISANVAGE, G.V. et al. Development of a polymerase chain reaction protocol for detection of Xylella fastidiosa in plant tissue. Phytopathology, St Paul, n.84, p.456-461, 1994.

PREJUÍZOS com a CVC. Informativo CCSM, v.6, n.12, p.3, 2001.

PURCELL, A.H. Cigarrinhas na cultura de citros. In: DONADIO, L.C.; GRAVENA, S. Manejo integrado de pragas dos citros. Campinas: Fundação Cargill, 1994. p.195-209.

PURCELL, A.H.; HOPKINS, D.L. Fastidious xylem-limited bacterial plant pathogen. Annual Review of Phytopathology, Palo Alto, v.34, p.131$51,1996$.

ROSSETTI, V.; DE NEGRI, J.D. Clorose variegada dos citros - revisão. Laranja, Cordeirópolis, v.11, n.1, p.1-14, 1990.

SAMBROOK, J. et al. Molecular cloning: a laboratory manual. 2. ed. New York: Cold Sprig Harbor Laboratory, Cold spring Harbor, 1989.

SHILLITO R.D.; SAUL M.W. Protoplast Isolation and Transformation. In: ..... Plant molecular biology: a partical approach. Dordrechet. Editora, 1988. v. 69, p. 181.

SOUZA, P. S.; DONADIO, L. C.; GONZALEZ-JAIMES, E. P. Avaliação de alguns genótipos de citros em relação à Clorose Variegada dos Citros (CVC). Revista Brasileira de Fruticultura, Cruz das Almas, v.22, n.2, p. 148-152, 2000.

WICKERT, E. Diversidade genética de Xylella fastidiosa avaliada por Polimorfismo de Nucleotídeo Simples (SNP). 2001. 89f. (Dissertação em Genética e Melhoramento de Plantas) - Faculdade de Ciências Agrárias e Veterinárias, Universidade Estadual Paulista, Jaboticabal, 2001. 